\title{
A SZLOVÁK KÖZIGAZGATÁS ÉS TERÜLETFEJLESZTÉS ASZIMMETRIÁI
}

\author{
(The Asymmetry of Slovak Administration and \\ Regional Development)
} MEZEI ISTVÁN - HARDI TAMÁS

\begin{abstract}
Kulcsszavak:
Határ menti kapcsolatok országok közötti aszimmetrikus viszonyok Szlovákia közigazgatási és területfejlesztési intézményrendszere.

Az Osztrák-Magyar Monarchia utódállamai arra törekedtek és törekednek napjainkban is, hogy egynyelvü nemzetállamokká váljanak. A sok évtizedes nacionalizmust azonban a racionalizmusnak kell felváltania, mert az egységesülö Európában a nyelvi (nemzetiségi, kulturális) alapokon nyugvó ellentéteknek (de nem a különbségeknek!) el kell(ene) porladniuk a „versenydemokráciák" keretei között müködö "piacgazdaságok" "jólétet" biztosító "tömegfogyasztási" gyakorlata során. Vajon a szlovák közigazgatás és a rápülö területfejlesztés mennyiben járul hozzá ehhez a régóta várt folyamathoz?
\end{abstract}

\section{Bevezetés}

A szociológia kitüntetett fogalma az egyenlőtlenség. Az általuk oly sokszor körbejárt társadalmi viszonyok, társadalmi egyenlötlenségek az egyes emberek egymás közötti egyenlötlenségéböl származtathatóak, mely egyenlötlenségek struktúrákat, szerkezeteket hoznak létre (strukturált egyenlötlenség [Giddens 1995]). Az emberi társadalmakat ma országhatárok választják el egymástól, mely országhatárok elhatárolják a politikai-gazdasági-jogi-közigazgatási stb. egységeket. Az állami szuverenitás keretbe foglalja az egyes országok társadalmainak bonyolult rendszerét. Az egyes országok a nemzetközi jog szerint egyenlöek, de mégis jelentős különbségek vannak közöttük, e különbségeket az aszimmetria fogalmával tudjuk legjobban kifejezni.

Az aszimmetria az egyes országok közötti különbözöségeket, eltéréseket mint létezó állapotot írja le, amit a szuverenitásra való tekintettel el kell fogadnunk. Ha ezeket az eltéréseket egy-egy ország politizáló közvéleménye egyenlőtlenségnek érzékeli és ennek fölszámolását a politikai vezetó réteg fölvállalja, akkor az egyenlőtlen állapotok feloldására szolgáló módszer a modernizáció gyakorlata. A modernizációs elméletek sok ország egyenlőtlenségi viszonyait elemzik, az általuk kidolgozott centrum-periféria viszony is számos országot érint.

Az aszimmetria fogalma különösen jól használható a határ menti kapcsolatok elemzésekor, mert a határ két oldalán lévő egyenlötlenségek az országok közötti szuverenitás miatt nem oldhatók meg a társadalmi egyenlőtlenségek feloldásának szokott módszereivel. Az egyéneknek, társadalmi csoportoknak be kell tartaniuk az országok egymás kỏzti viszonyait szabályozó törvényeket. A határ menti kapcsolatok esetében az országok között fennálló versenyhelyzet is más dimenzióba kerül. 
A kapcsolatot kiépítỏ szervezeteknek mindig az egyenjogúság elvén kell állniuk, a cselekvéseknek tartalmazniuk kell a kölcsönösség elvét. Amennyiben az egyenlöség és a kölcsönösség elvét valamelyik fél megsérti, akkor emögött az országok közötti egyenlötlenség, hatalmi-politikai-gazdasági stb. súlykülönbség húzódik meg.

Ennek az aszimmetrikus viszonynak a vizsgálata azért is érdemel figyelmet, mert az országokon belüli fejlödés mértéke már rég túllépte az országhatárokat, sőt az Európai Unió létrejöttének egyik fő mozgatója volt a gazdaság fejlödése előtt álló akadályok, köztük az országhatárok gátló hatásának a fölszámolása. Mivel ez a folyamat a jelenlegi tagállamok között már évtizedekre visszanyúló törekvések eredménye, mára úgy érezzük, a tények ellenére, hogy a tagállam-tagállam kapcsolat nem, vagy alig tartalmaz egyenlötlenségeket, illetve az egyes államok, határ menti területek sajátosságait úgy alakították, hogy a hagyományokból fakadóan meglévő aszimmetriák nem gátolják az együttmüködést.

Ezzel szemben a tagállamok és a most csatlakozó országok között jelentős fejlödésbeli eltérések vannak. Az egyenlőtlen viszonyok aszimmetriákból szövődnek össze. Eltérőek a jogrendszerek, az államigazgatási, a közigazgatási viszonyok, az önkormányzatiság foka, a gazdasági szereplők száma, sürüsége és ereje, de a civil szervezetek száma, ereje, a feladatellátásban betöltött súlya is. Ezeket a fennálló különbségeket egy értékelő elemzésben összességében egyenlötlenségnek minösíthetjük, amelynek a leküzdésére, a felzárkózásra modernizációs eszközökkel reagálhatnak a versenyben lemaradó államok.

Az önálló fejlödés következtében a csatlakozó országok között is fennállnak a jogrendszer, a közigazgatás, az államigazgatás, a gazdaság, a civil szervezetek stb. sajátosságai. Ezeket az eltéréseket is érdemesebb aszimmetriának neveznünk, az egyenjogú, szuverén államokra való tekintettel, miközben megállapíthatjuk, hogy léteznek (vagy nem is léteznek) egyenlötlenségek közöttük. A csatlakozó országok között ugyanis jóval több a hasonlóság a közös történelmi múlt miatt, mint a tagállamok és a csatlakozók között.

$\mathrm{Az}$ aszimmetrikus viszonyok föltárásának azért van jelentősége, mert rá tud mutatni azokra a különbségekre, amelyek akadályozzák a határ menti kapcsolatok kiszélesedését. A szomszédsági együttmüködések fö tanulsága az, hogy ha van politikai szándék, akkor a fennálló különbségek, eltérések, aszimmetriák felszámolhatók. Elképzelhetők olyan államok közötti viszonyok is, amikor a politikai szándék nem a kapcsolatépítésre helyezi a hangsúlyt, hanem az aszimmetriák fönntartására, hogy ezzel akadályozza a neki nem tetsző együttmúködési formákat. A Kárpátok Eurorégió története bövelkedik ilyen eseményekben (Süli-Zakar 2000). Ezt a jelenséget egyáltalán nem kell kelet-közép-európai sajátosságnak tekinteni, mert ahol a határok nem összekötő szerepet játszanak, ott az elkülönítésnek, az aszimmetrikus rendszerek kiépítésének különféle technikáit alkalmazzák. Útlevél, szögesdrót, eltérö jogrendszerek, össze nem illeszthetö államigazgatás stb. a világ sok határát jellemzi. 
Meg kell vizsgálnunk, hogy Magyarország és Szlovákia között milyen különbségek vannak, a két ország aszimmetrikus eltérései milyen mértékben közeledtek egymáshoz. Ennek során bogozható ki, hogy Szlovákia milyen szinten kapcsolódik az Európai Unióhoz, illetve a Magyarország és Szlovákia között létezö szomszédsági kapcsolatok milyen fokú együttmüködést tesznek lehetővé. Ezt két fontos témakörben mutatjuk be, a közigazgatás és a területfejlesztés, illetve a hozzájuk kapcsolódó területi különbségek esetében.

\section{Közigazgatás}

A békeszerződés nyomán 1920-ban fölálló Csehszlovákia, majd Szlovákia (1939-1945, 1993-tól) feltủnő sürüséggel alakította közigazgatásỉ rendszerét. Ennek oka egyrészt, hogy az államforma kifejeződik a közigazgatás területi felosztásában és az átadott jogosultságok mértékében. Ez jelentős különbségekhez vezetett a polgári Csehszlovákia demokratikus és a kommunista diktatúra centralizált állami-igazgatási berendezkedése között.

A másik figyelemre méltó tényezỏ azonban az, hogy Csehszlovákia egy soknemzetiségủ állam lett, amit sem ideológiájában, sem igazgatási rendszerében, sem mindennapi gyakorlatában nem vállalt fel, söt a cseh nacionalizmus törekvése az volt, hogy egynemủ, egynemzetiségü, azaz csehszlovák nemzetiségủ államot hozzon létre. Ennek legfőbb akadálya volt a több mint 3 milliós (3319 ezer fö 22,53\%) német és a 719 ezer fős (4,89\%) magyar kisebbségek jelenléte az 1930-as népszámlálás szerint (Csehszlovákia II. é.n.). Az új állam erős cseh nacionalizmusára (és a szlovák fél gyengeségére) volt jellemzỏ, hogy a szlovákok nemzeti létét is csak hosszú küzdelem után kezdte elismerni. Mindenesetre az új állam saját hatalmának kiépítése, folyamatos erősítése és a nemzetiségek gyengítése érdekében nagy gyakorisággal változtatta közigazgatásának területi felosztását. Ezt a sorozatot mutatja be az 1. táblázat.

\begin{tabular}{lcc} 
1. TÁBLÁZAT \\
& $\begin{array}{c}\text { Szlovákia területi-államigazgatási beosztási rendszere } \\
\text { (The Regional and Administrational Division of Slovakia) }\end{array}$ \\
\hline & Nagyobb területi egység & Kisebb terïleti egység (járás) \\
\hline-1918 & 10 vm+10 töredék vm & $85+8$ töredék \\
1922 & 6 nagyzsupa & 85 (Kárpátaljával együtt) \\
1927 & 2 tartomány & 77 \\
1939 & 6 nagyzsupa & 59 \\
1945 & - & 79 \\
1949 & 6 kerület & 92 \\
1960 & 3 kerület & 35 (késöbb+4) \\
1968 & 4 kerület & 39 \\
1990 & - & 121 körzet (obvody) \\
1996 & 8 megye/kerület & 79 \\
\hline
\end{tabular}

Forrás: Petö́cz 1998 alapján saját szerkesztés. 
1922. január 1-jén bevezették a nagyzsupák rendszerét. Hat nagymegyét (nagyzsupát) hoztak létre, újonnan meghúzott belső határok mentén, vigyázva arra, hogy a keleti, szlovák területeken a magyarok sehol se lehessenek többségben. A kormány még azt a jogot is fenntartotta magának, hogy a nagymegyék képviseló testületébe maga nevezte ki a képviselök harmadát. Ök többnyire csehek voltak (Popély 1995).

A nagyzsupák rendszerét 1927-ben megszüntették, létrehozták a tartományi rendszert. A korabeli Csehszlovákia keleti részét ennek megfelelöen osztották fel két tartományra: Szlovákiára és Kárpátaljára. A járási felosztás megmaradt. A tartományi önkormányzat képviselöinek egyharmadát most is a prágai kormány nevezte ki. Az 1939-ben megalakult önálió Szlovák állam új közigazgatása visszaállította a nagyzsupák rendszerét. Hat nagyzsupát hoztak létre, kissé módosított határokkal a déli, Magyarországhoz visszacsatolt részek nélkül.

1945-ben újjáalakult Csehszlovákia, de már Kárpátalja nélkül. A régi járások újjászerveződtek, de a megyék nem. Ez azonban nem hozott könnyebbséget, mert a Benes-dekrétumok miatt a magyaroknak nem volt választójoga, közügyeket nem gyakorolhattak, nem tölthettek be semmilyen államigazgatási tisztséget.

A kommunista hatalomátvétel után 1949 januárjától ismét új közigazgatási rendszert vezettek be. Újból létrehozták a hat közigazgatási egységet, megye helyett kerület néven. Egyetlen kerületen belül sem lettek a magyarok többségben. A járások száma nőtt, de a magyar többségú járások száma csökkent a magyarok deportálása, kitelepítése, valamint a megfélemlítés miatt. Sokan nem merték magyarnak valiani magukat a hátrányok miatt. A jelenség érzékeltetésére álljon itt egy népességi adat. 1930-ban 592337 magyart mutatott ki a népszámlálás Szlovákia mint tartomány terúletén, 1950-ben csak 354 532-t. Ezért lehetett az ötvenes években hivatalosan csak hét magyar többségú járás a tényleges 13 helyett (Petốcz 1998, 161).

A kommunizmus évtizedeiben a közigazgatás teljes egészében a központi hatalom végrehajtó szerveként müködött. Az ún. nemzeti bizottságok (tanácsok) még csak formálisan sem feleltek meg a szabad képviselôválasztás elvének az egypártrendszer körülményei között, mert helyi, járási és kerületi szinten nem volt különválasztva az államigazgatás az önkormányzati rendszertől. A helyi aktivitásnak csak kis teret engedett a központi igazgatás. Ez felelt meg az állami tulajdonlás rendszerének.

1960 és 1989 között jelentös átalakításra került sor a közigazgatásban. 1960-ban nagyszabású centralizáció történt. A kerületek száma háromra, a járásoké 35-re csökkent. A kerületi határokat úgy alakították, hogy a magyarok aránya csak Nyugat-Szlovákiában haladta meg a $20 \%$-ot, másutt mindenütt mélyen $10 \%$ alatt volt. A járások közül csak kettőben volt a magyarok részaránya 50\% fölött (a komáromi és a dunaszerdahelyi járásban), további nyolcban pedig 20-50\% között volt. 1968-ban Pozsonyt külön kerületnek minősítették, és ezzel egyúttal néggyel nőttt a járások száma.

1990-ben a Szlovák Nemzeti Tanács megreformálta, az európai normákhoz igazította a szlovák kỏzigazgatást. Ekkor különulit el újból egymástól az államigazgatás 
és a választott községi önkormányzat. Megkezdődött a diktatúra közigazgatási rendszerének fölszámolâsa és az önkormányzati hagyományok felújítása, de erős aszimmetriával, mert csak az egyes települések kaptak önkormányzati jogokat, a közigazgatás többi szintjén maradt az állami-hivatali rendszer. Az önkormányzatiság bövülése azóta is folyamatos politikai harcok közepette folyik, lépésről lépésre.

A települési önkormányzatok 1990-től kezdve maguk döntik el saját hivatalaik belső szervezeti és müködési rendjét, alkalmazkodhatnak településủk adottságaihoz. Ettől az évtól a nagy kerületek megszüntek, a járásokat kisebb egységekre, körzetekre (obvody) osztották. A körzetek száma 121 volt 1996 júliusáig. A 121 körzetbỏl 17-ben haladta meg a magyarok részaránya az 50\%-ot, hatban volt 20-50\% között, hétben 5\% fölötti és 12-ben $1 \%$ fölött.

1996-ban (most már a független szlovák államban) új közigazgatási beosztás született. Az akkor uralkodó szlovák nacionalista pártok a közigazgatási rendszer átalakításával egyrészt egy központosító politika szervezeti rendszerét akarták kiépíteni, másrészt pedig az ellenzéki választási körzeteket akarták megosztásukkal gyengíteni. Mivel a reformok legkövetkezetesebb hívei a kereszténydemokrata ellenzék és a magyarok voltak, az ỏ megosztásukat több érdek is indokolta. Mivel ez a törvény sarkalatos jelentőségủ a szlovák közigazgatás történetében, hangsúlyosan meg kell ismételni, hogy a magyarok lakta területek megosztása csak egyik (de természetesen nagyon fontos) indoka volt a létrejött szerkezetnek, a másik ok kifejezetten belpolitikai-választási jellegủ volt. Vagyis, másként fogalmazva, a közigazgatás szervezésében a választási-nemzetiségi ellentétek mögött a nacionalista és a modernizációs politikai csoportosulások ellentéte húzódott meg és húzódik meg mindmostanáig, és nem a gazdasági-fejlettségi különbségek fejeződnek ki, nem a történelmi hagyományok bukkannak föl, nem a lakosság ellátásra vonatkozó igényeit akarták elsősorban kielégíteni stb.

A közigazgatás kezdő és végpontját, tehát a történelmi Magyarországtól örökölt megyerendszert és az 1996-tól érvényes új beosztást mutatja az 1-2. ábra.

Az 1996-os törvény központosító szándékának bizonyítéka, hogy az önkormányzati jogkört csak a településeken hagyták meg, azonban ezt a jogkört nem bỏvítették, mert a járások és a kerületek hivatalai is mind a minisztériumok hatáskörébe tartoztak. Kezdetben minden egyes minisztérium külön-külön felügyelte a saját szerveit, később ezeket a hivatalokat összevonták, a belügyminiszter felügyelete alá rendelték, és csak ezen belül tartottak kapcsolatot tevékenységi körönként az egyes szakminisztériumokkal. A pénzügyi függés viszont még ennél is teljesebb volt, mert a közigazgatás minden szintje a központi költségvetésből és csak onnan kapott forrást a múködéshez. A beruházásokhoz szükséges összegek előteremtése így teljesen láthatatlan csatornákon történt. Ez sok város eladósodását idézte elö, mert az így-úgy (vagyis politikai szimpátián alapuló kijárás útján) megszerzett pénz visszafizetésére az ígéretek ellenére sem kapták meg az állami garanciát. 


\section{1. ÁBRA}

A Magyarországtól örökölt megyék Szlovákiában, 1920

(he Counties Inhereted from Hungary in Slovakia, 1920)

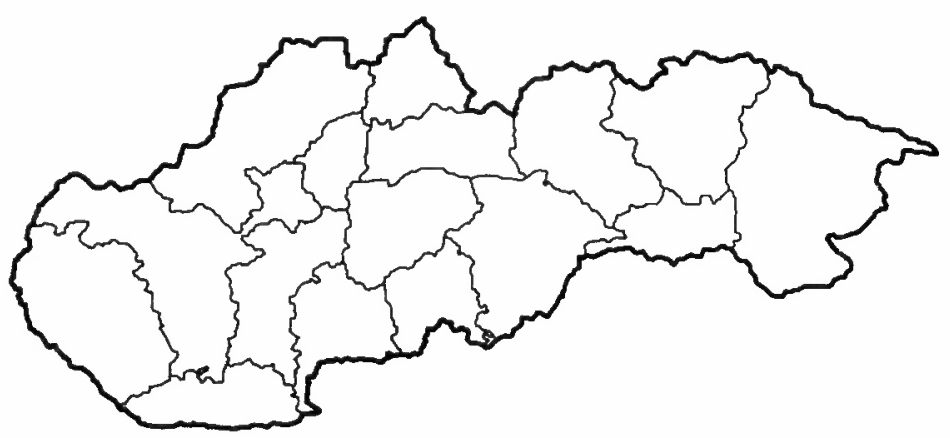

Forrás: Popély 1995 alapján MTA RKK, Miskolc, Mádi Máté geográfus.

\section{2. ÁBRA}

Az 1996-tól érvényben lévö megyei és járási beosztás Szlovákiában

(Borders of Counties and Districts in Slovakia since 1996)

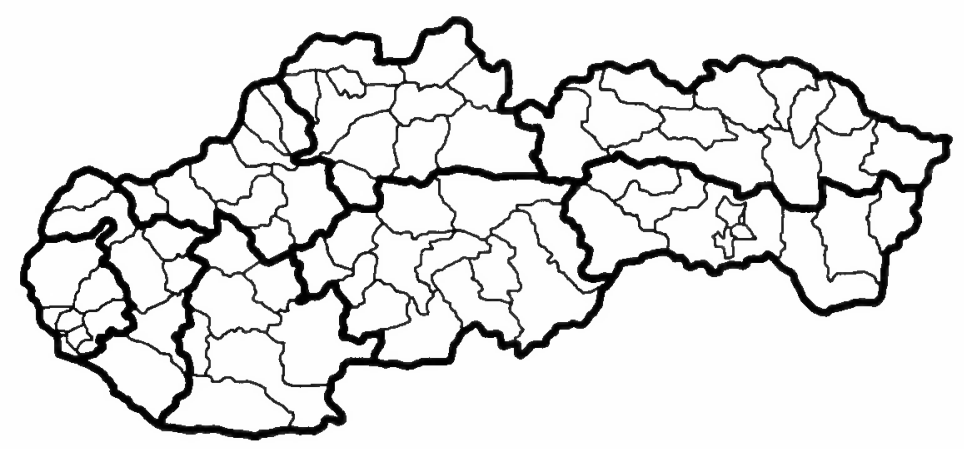

Forrás: http://europa.eu.int/abc/maps alapján MTA RKK, Miskolc, Mádi Máté geográfus. 


\section{TÁBLÁZAT}

A közigazgatás (állami és önkormányzati) területi egységei Szlovákiában (Regional Units of National and Local Governmental Administration in Slovakia)

\begin{tabular}{|c|c|c|c|c|c|c|}
\hline & $\begin{array}{l}\text { Szlo- } \\
\text { vák }\end{array}$ & Angol & Magyar & $D b$ & Névváltozat & Funkció \\
\hline NUTS 1 & straná & state & ország & 1 & & \\
\hline NUTS 2 & & region & régió & 4 & & $\begin{array}{l}\text { területi statisz- } \\
\text { tikai egység, } \\
\text { adminisztratív } \\
\text { régió }\end{array}$ \\
\hline NUTS 3 & kraj & $\begin{array}{l}\text { county, } \\
\text { region } \\
\text { HTU, } \\
\text { (Higher } \\
\text { Territo- } \\
\text { rial } \\
\text { Unit) }\end{array}$ & megye & 8 & $\begin{array}{l}\text { Kerület (állami } \\
\text { hivatal) } \\
\text { Megye (önkor- } \\
\text { mányzati szer- } \\
\text { vezet) } \\
\text { Másodfokú } \\
\text { területi egység }\end{array}$ & $\begin{array}{l}\text { önkormányzati } \\
\text { testület } \\
\text { +államigazgatá- } \\
\text { si kerület hiva- } \\
\text { talai }\end{array}$ \\
\hline NUTS 4 & okres & district & $\begin{array}{c}\text { járás, } \\
\text { kistérség }\end{array}$ & 79 & $\begin{array}{l}\text { közigazgatási } \\
\text { körzet; elsőfokú } \\
\text { területi egység; } \\
\text { 1996-ig } 121 \mathrm{db} \\
\text { körzet (obvody) }\end{array}$ & $\begin{array}{l}\text { államigazgatási } \\
\text { egység }\end{array}$ \\
\hline NUTS 5 & $\begin{array}{l}\text { obec- } \\
\text { mesto }\end{array}$ & $\begin{array}{l}\text { muni- } \\
\text { cipality }\end{array}$ & $\begin{array}{c}\text { Telepü- } \\
\text { lés (vá- } \\
\text { ros+falu) }\end{array}$ & 2878 & Önkormányzat & $\begin{array}{l}\text { Önkormányzat } \\
\text { + saját hivatala }\end{array}$ \\
\hline
\end{tabular}

Forrás: Saját szerkesztés.

Szlovákia 2866 községét 8 nagy államigazgatási kerületbe és 79 járásba sorolták (2. táblázat). A kerületek nagyjából hasonló lélekszámúak lettek, de területileg nagyok a különbségek. Emellett új városokat jelöltek ki központi szerepre, amelyek bizonyítják, hogy a politikai vezetés a választási szempontok figyelembevételével jutalmazta (Trencsén), illetve büntette (Szepesség) a nem Meciarhoz húzó területeket. Ebböl a szempontból a leglátványosabb tett a szlovák többségủ Szepesség kettévágása volt.

Ez a megosztó politika érvényesült a magyarlakta vidékeken is, amelyeket ennek a szándéknak megfelelỏen daraboltak fel. A hegy mögötti Besztercebánya (Banská Bystrica) a mindig megyeszékhely Rimaszombattól (Rimavská Sobota) vette át a központi szerepet. A Csallóközt, a tömbmagyarság területét kettéválasztották. Egyik részét a szlovák Nagyszombathoz (Trnava) csatolták, melynek megközelítése csak keruilővel, Pozsonyon keresztül történhet az ügyintéző többség számára, másik részét pedig a nyitrai (Nitra) kerületbe. Az eddig külön álló szomszédos párkányi körzet is ide került. Petícióval tiltakozott Tornalja körzetének lakossága a járás megszüntetése ellen, a kormány mégis a tiszta szlovák Nagyröcéhez csatolta a települést, amely északra, a hegyen túl van $50 \mathrm{~km}$-re. Ugyanígy elutasították a hagyo- 
mányos királyhelmeci, párkányi, nagymegyeri, zselízi, somorjai és ipolysági járások fennmaradását is.

A helyzeten az említett telepuilések úgy enyhítettek, hogy kihasználták az önkormányzati törvény adta lehetöségeket az önkéntes feladatvállalásra. Erre példa, hogy habár Királyhelmectöl elvették járási jogosítványait, a văros mégis úgy döntött, hogy tekintettel a környékén lévő kis települések sokaságára, továbbra is ellát terïleti szervezési, fejlesztési feladatokat, így nem kell a falvak vezetöinek a messzi és szlovák nyelvü Terebesre utazniuk.

$\mathrm{Az}$ aránytalanság a járások kialakításában mutatkozik meg legjobban. A szlovákok lakta kerületekben kisebb és így több járást alakítottak ki, míg a magyarok által lakott községek többségét egy-egy nagy (100 ezer lakos fölötti) járásba vonták össze. Ezzel a módszerrel érték el, hogy 1990-hez képest tízröl kettỏre (!) apadt a $20 \%$ feletti magyar részaránnyal bíró járások száma, a kerületi központok pedig mindig a nyelvhatáron kívül esnek. Hasonlóképpen szervezték meg a járásokat a ruszinok lakta keleti részeken is.

A hagyományoktól való durva eltérést észrevételezte az Európa Tanács ajănlása is: „elkerülendö, hogy a közigazgatás átalakításánál adminisztratív akadályok gördüljenek a kisebbségi nyelvek és kultúrák fejlödése elé" (Petöcz 1998, 172).

Az önkormányzati rendszer, azon belül is a régiók kialakítása csak formális demokráciát valósított meg, mert mind a hagyományoknak, mind a gazdasági érdekeknek, mind az igazgatási racionalitásnak ellentmondva politikai-választási és nemzetiségi szempontokat vett figyelembe, vagyis az ellenzéki területek megosztására törekedtek, valamint a magyarok, ruszinok, cigányok létszámának $20 \%$ alá szorításának céljával jelölték ki a területeket. A törvények pedig ezen túl mindig olyan megoldásokat tartalmaznak, nehogy a városokban, illetve a kerületekben valaha is magyar többség alakulhasson ki.

A szlovákiai magyar pártoknak nem sikerült elfogadtatni a területi önkormányzatiság elvét, illetve a területi önkormányzatiság a szlovák nacionalista párt választási és nemzeti érdekeinek megfelelően valósult meg. Ez konkrétan azt jelentette, hogy a Meciart támogató északi teruileteken több kisebb, míg az ellenzéki délen nagyobb, de kevesebb számú választókörzetet hoztak létre a választási eredmény számukra kedvezö elökészitése érdekében (Petöcz 1998, 172).

A magyar szervezeteknek a rendszerváltás óta kidolgozott elképzeléseik vannak a nemzeti kisebbségek és etnikai csoportok egyéni és csoportos jogainak megvalósításáról, helyi, regionális és országos önkormányzati szerveik létrehozásának szükségességéröl. Ezeket a javaslatokat a szlovák parlament rendre és mindig visszautasította, helyettük - tekintet nélkül a nemzetiségi igényekre - kizárólag a szlovák érdekeknek megfelelő önkormányzati törvényt fogadtak el. A társnemzet, az intézményesített egyenjogúság megteremtésére törekvő magyar elképzeléseket is ugyanígy visszautasították (Duray 2000).

Mindez azt mutatja, hogy Szlovákia még mindig nemzetiségi problémákkal küszködik, erejének jó részét még mindig arra pazarolja, hogy minél hamarabb megfelel- 
jen az egységes nemzetállam kritériumainak, és csak ez után tartja fontosnak a települések, a népesség, a lakosság kisebb-nagyobb csoportjainak önrendelkezését. A közigazgatás nacionalista célú változtatása szétszabdalja a hagyományos kötődéseket, az összetartozás oly fontos szálait, fölösleges feszültségeket kelt a lakosokban, elvonja a figyelmet a jóléti társadalom építésétöl.

A szlovák nemzeti igények, pontosabban a szlovák nacionalista kormány demokratikus reformokat nem támogató híveinek kielégítésére formált közigazgatás egyúttal a hivatalok és a hivatalnokok számának a növelését is maga után vonta. 1997-ben minden 45 lakosra jutott egy közigazgatási dolgozó (Halász 2001, 57). A központosítás és az önkormányzatiság arányát érzékeltethetjük azzal is, hogy az államigazgatás három szintü, az önkormányzatiság viszont csak egy (települési) szintủ volt.

Az 1998-ban kormányra került polgári erök a közigazgatás reformját határozták el. Ebben erős támogatókra leltek a Falvak és Városok Szövetsége nevủ szervezetben. Hosszú politikai csatározások után 2001-ben sikerült elfogadtatni a megyei önkormányzatok megalakításáról szóló törvényt. Ennek jegyében tartották meg a választásokat még ez év decemberében. A felálló megyei önkormányzatok első számú vezetöjét közvetlenül a lakosság választja, helyettesét a képviselötestület soraiból maga választja $\mathrm{ki}$, az önkormányzati hivatal vezetői tisztségének betöltésére pedig - a koalíciós pártok közötti megegyezés alapján - az elnök kéri fel az illetö párt jelöltjét (ez a feladatkör kb. a magyar föjegyzönek felel meg). Tehát a megyei önkormányzatok elsỏ három tisztségviselỏje a politikai-választási verseny alkufolyamataiból kerül ki.

Az önkormányzatok hatáskörét kiterjesztették az oktatásra, egészségügyre, szociálpolitikára, a közlekedés és az infrastrukturális szolgáltatások körére. Különösen fontos, hogy a területfejlesztés és a tervezés hatásköre is átkerült a megyékhez. Korlátozza az önkormányzatok hatáskörét, hogy viszonylag kevés olyan tevékenység van, ami alapfeladatnak minősül, mert jelenleg pénz hiányában önként vállalt feladatokat alig tudnak teljesíteni. Ilyen alapfeladat a területfejlesztés. A feladatok döntö részét az állam a törvénynek megfelelöen átadja, de vissza is veheti. Ilyen az oktatásügy. A rendszerbe bevonták a polgári szervezeteket, az ún. harmadik szektort is, mert azok átvállalhatnak állami-önkormányzati feladatot (pl. a szociálpolitika területén), a müködéshez szükséges összeget pedig átutalja számukra a megye.

A hatáskörök átadása-átvétele még folyamatban lévö ügy, de ezen kívül is több fontos törvény hiánya nehezíti az önkormányzatok munkáját. Ezek közé tartozik az adózásról szóló tởrvény, amely rendezné az önkormányzatok pénzügyi forrásait. Jelenleg nincs önálló bevétele az önkormányzatoknak. A régi, központosított rendszer van érvényben, azaz minden adóbevétel az államhoz kerül, ezt osztja vissza parlamenti megegyezés alapján az állam az önkormányzatoknak. Ez a rendszer egyrészt sok bizonytalanságot takar, mert évről évre változhat az arány, amit a parlament megszavaz az önkormányzatoknak, másrészt hiányzik a fejlesztésekhez szükséges pénzelosztási rendszer kiépítése, így bizonytalan az is, hogy ki és mekkora összeget, milyen elvek alapján kap a felújításokhoz, fejlesztésekhez. 
Az intézményeket fenntartó önkormányzatok jogai abban a kérdésben sem teljesek, hogy sem az egyes intézmények költségvetésének meghatározásában, sem a vezetők kiválasztásában nincs teljes jogkörük. Az iskolaigazgatók esetében a kijelölés és a választás szervezete az iskolatanács, viszont ebben a 11 tagú testületben az önkormányzat is és a járás is csak egy-egy küldöttel képviselteti magát, miközben a szülő́k négy fövel és velük azonos számban az iskolai alkalmazottak (két pedagógus, egy nem pedagógus és egy szakszervezeti küldött). Mindezek után az igazgató kinevezése és a vele járó felelősség az önkormányzaté. A járások (azaz az állami hivatalok) már csak szolgáltató (bérkifizető) funkcióval bírnak, nincs jóváhagyási jogkörük ebben a kérdésben sem.

A tervek szerint az államigazgatási kerületek, ha át is adják feladataikat a megyei önkormányzatoknak, az egyes minisztériumok hatóságai, feladatellátó szervei ide települnek, létrehozzák a maguk dekoncentrált szerveit.

Új jelenség, az erősỏdő önkormányzatiság jele, hogy a megyei választott képviselők nyomására a „szélsőségesen kerekített”, a torzul formált megyékben dekoncentrált szerveket, kihelyezett hivatalokat hoztak létre a lakosság igényeinek kielégítésére a hagyományos területi súlypontokban. Így került ismét kihelyezett megyei hivatal a Besztercebánya központú megyében Rimaszombatra, illetve a Nyitra központú megyében Révkomáromba az ügyintézés meggyorsítására.

1990 óta Szlovákia elindult azon az úton, amely a jogállamiság megerösödése felé vezet. Ennek tartalma az, hogy az önkormányzat azt tehet, amit a törvény nem tilt, a hivatal viszont csak azt teheti, amit a törvény elöír. Az önkormányzatiság erősödése, az állami-hivatali hatalom fokozatos visszaszorulása megkezdődött, de a folyamat ellentmondásosságát érzékeltetik azok a kritikai hangok, amelyek szerint a szlovák közigazgatás egy emberarcú kentaurra hasonlít, amely kifelé Nyugat, befelé Bizánc ${ }^{1}$.

\section{Területi különbségek Szlovákiában}

A közigazgatás területi határainak kijelölésében mutatkozó sokféle bizonytalanság és bizalmatlanság azért is kaphatott ekkora jelentőséget, mert Szlovákia gazdasági fejlettsége rendkívül sajátos. Az ország legnyugatibb pontján található Pozsony és szükebb környezetének fejlettsége mellett kelet felé haladva egyre fejletlenebb területekkel találkozhatunk. A gazdaság átalakulása még a közigazgatáshoz képest is több kívánnivalót hagy maga után, emiatt a gazdaság nem tudott meghatározó erővel beleszólni a közigazgatás formálásába. A gazdaság ellentmondásos helyzetét a területi különbségekkel tudjuk legjobban érzékeltetni.

A kommunizmus évtizedei alatt a terület- és településfejlesztési politika hatására új térségi megoszlás jött létre. A hadi célokat szolgáló eröltetett iparfejlesztés (bányászat, nehézipar) párosult a városfejlesztéssel, amelynek a célja a rendszerhủ munkásosztály (és értelmiség) kialakítása volt. A szlovák részek néhány városában erỏteljes fejlesztés volt, kơzülük kiemelkedik Kassa (Kosice) vas- és acélgyártó tevékenysége, ami az orosz vasérc feldolgozására épült. Ennek kedveért még széles nyomtávú orosz vasúti sínpárt is kiépítettek a határtól a gyárig, az átrakodás elkerülése érdekében. 
Felfedezhetjük ebben az ipartelepítési logikában a politikai és stratégiai-védelmi szempontokat is, mert az ország legkeletibb részén, közel az akkori szovjet határhoz építették meg ezeket a ténylegesen fegyvereket gyártó hadi üzemeket, messze a nyugati határtól és - metaforikusan fogalmazva - messze a világpiaci hatásoktól. Ez az ipar nem szervesült egy általános gazdasági fejlödéshez, idegen maradt az országon belül is. Addig nyújtott foglalkoztatottságot és jólétet, amíg a szovjet megszállás tartott, annak elmúltával válságba zuhant a régió.

\section{Területi különbségek a régiók szintjén}

Az európai statisztikai elemzések a NUTS 2 szinten kifejezik az egyes régiók gazdasági fejlettségét a GDP mutatói segítségével (3, táblázat). Ebben az összefüggésben Pozsony fejlettsége megegyezik az Európai Unió átlagával, és a csatlakozó országok közötti sorrendben rögtön az első helyezett Prága után következik. Ellenben Kelet-Szlovákia csak az Unió átlagának 39\%-át éri el, amivel 23. a sorrendben. Jegyezzük meg, hogy a pozsonyi régió csak a fövárosra és a legszükebb környékére terjed ki, szemben a Közép-magyarországi régióval, amely Budapesten kívül magában foglalja Pest megyét is, illetve a kassai vasmủ az új amerikai tulajdonos kezében nyereséges nagyvállalattá vált, ami kiemeli az amúgy is egyetlen keleti nagyvárost a kelet-szlovákiai régió általános szegénységébỏl.

3. TÁBLÁZAT

Az egy före jutó regionális GDP Szlovákiában és Magyarországon (The Regional GDP per Capita in Slovakia and Hungary)

\begin{tabular}{lcc}
\hline & Egy före jutó GDP & $\%$ \\
\hline \multicolumn{1}{c}{ Európai Unió - 15 ország } & 2098 & $\%$ \\
$\quad$ Magyarország & 9899 & 100 \\
Közép-Magyarország (legfejlettebb) & 14633 & 49 \\
Észak-Alföld (legszegényebb) & 6700 & 72 \\
$\quad$ Szlovákia & 9828 & 33 \\
Pozsony (Bratislava) & 20092 & 49 \\
Nyugat-Szlovákia & 8962 & 99 \\
Közép-Szlovákia & 8503 & 44 \\
Kelet-Szlovákia & 7931 & 32 \\
\hline
\end{tabular}

Forrás: Eurostat, Statistics in Focus, General Statistics 1998.

\section{Területi különbségek a kerületek/megyék szintjén}

A regionális (NUTS 2 szintủ) különbségek tovább finomodnak az államigazgatás kerületi, később (2001 decemberétól) az önkormányzatok megyei szintjén. A reformfolyamatok nagy területi különbségeket eredményeztek, mert a kifejlödő piacgazdaság a jobb infrastruktúrájú és magasabb fizetőképes kereslettel bíró településeket keresi. 1997-ben az akkori közigazgatási beosztás szerint meglévő nyolc 
NUTS 3 kerület legerősebbike, a pozsonyi és a leggyengébbik, az eperjesi (Presov) között hatszoros volt a GDP különbsége.

A 4. táblázat népességi adatait összevetve a gazdasági mutatókkal szembe tủnik a szlovák kerületi, illetve megyerendszer fonáksága. Láthatóan arra törekedett a politikai vezetés, hogy lélekszámát tekintve közel hasonló számú népességủ kerületek/megyék jöjjenek létre. Az itt lévő viszonylag kis különbségekhez képest azonban a többi mutató nagy aránytalanságokat jelez.

Egyrészt Pozsony minden mutatóját tekintve kiemelkedően jó helyzetben van. Itt van a legtöbb vállalkozás, négyszer annyi mint Nagyszombat kerületben. A külföldi tőke itt jelenik meg a legnagyobb arányban, 14-szer nagyobb arányban, mint Eperjes kerületben. Kiemelkedően sok a külföldi beruházás, a zsolnai kerülethez képest majdnem hússzoros. Ennek megfelelően alacsony a munkanélküliek aránya, majdnem negyede a kassainak. Pozsonyban minden 26 munkanélkülire jut egy betöltetlen állás, Kassa megyében 266 munkanélkülire jut egy. A pozsonyi térségnek van a legjobb infrastruktúrája, kutatási és fejlesztési $(\mathrm{K}+\mathrm{F})$ potenciálja, és ez a régió közvetlenül határos az Európai Unióval az osztrák szomszédság miatt.

\section{TÁBLÁZAT}

A szlovák megyék néhány fejlettségi mutatója, 1999-2000 (\%) (Some Development Indicators of Slovak Counties, 1999-2000)

\begin{tabular}{lcccccc}
\hline & $\begin{array}{c}\text { A teljes } \\
\text { népessé- } \\
\text { gen beliuli } \\
\text { arány }\end{array}$ & $\begin{array}{c}\text { Vállal- } \\
\text { kozások } \\
\text { aránya }\end{array}$ & $\begin{array}{c}\text { A gazdasá- } \\
\text { gilag aktív } \\
\text { népesség } \\
\text { aránya }\end{array}$ & $\begin{array}{c}\text { Munka- } \\
\text { nélküli- } \\
\text { ekará- } \\
\text { nya }\end{array}$ & $\begin{array}{c}\text { A kül- } \\
\text { földi } \\
\text { töke } \\
\text { aránya }\end{array}$ & $\begin{array}{c}\text { A külfóldi } \\
\text { beruházá- } \\
\text { sok aránya }\end{array}$ \\
\hline Pozsony & 11,5 & 31,2 & 13,1 & 6,8 & 51,9 & 60,5 \\
Nagyszombat & 10,2 & 7,2 & 10,2 & 15,7 & 8,0 & 10,0 \\
Trencsén & 11,3 & 9,6 & 11,6 & 13,5 & 8,3 & 6,4 \\
Nyitra & 13,3 & 8,7 & 13,0 & 22,7 & 6,3 & 3,8 \\
Zsolna & 12,8 & 10,0 & 13,0 & 17,7 & 7,5 & 3,1 \\
Beszterce- & 12,3 & 11,2 & 12,2 & 22,8 & 6,6 & 4,9 \\
bánya & 14,5 & 9,5 & 13,5 & 23,2 & 3,6 & 3,6 \\
Eperjes & 14,2 & 12,7 & 13,4 & 25,5 & 7,9 & 7,7 \\
Kassa & & & & & & \\
\hline
\end{tabular}

Forrás: Szlovák Statisztikai Hivatal.

$\mathrm{Az}$ összes többi régióban a gazdaság elsỏ szektorában (mezőgazdaság, erdészet) dolgozik a népesség 10-20\%-a, 30-50\%-a a második szektorban (ipar), és hasonlóan ekkora (30-50\%) a harmadik szektorban (szolgáltatások) foglalkoztatottak aránya. A pozsonyi régióban ez utóbbi arány $69,7 \%$, az iparban dolgozók aránya $27,5 \%$, és a mezőgazdaság csak a népesség $2,8 \%$-át foglalkoztatja. Ugyanilyen éles különbségek jellemzóek a munkanélküliségre is, mert itt csak 4\% körüli a munkanélküliségi arány, míg a déli és az északi határtérségekben $30 \%$ fölötti. Az ingázás különösen a cseh és az osztrák határ mentén elterjedt kenyérkereseti forma. A politikai és társadalmi-gazdasági jellemzők különbségeiböl adódóan sok akadály létezik az országok közötti kapcsolatokban, de ezek csökkenhetök egy új határ menti politikával. 
A területi különbségek fontos összetevője a képzettségi szint. A fejlettség és a fejlesztési lehetőségek erősen összefüggenek a foglalkoztatottak iskolai végzettségével. A megyei adatok átlagokat mutatnak, viszont köztudott, hogy a magasabb szintủ iskolákkal rendelkezỏ nagyvárosok több magasabban képzett munkaerỏvel rendelkeznek. Ezt a magasabb arányszámot azonban a kisebb települések adatai lerontják. Másrészt nincs közvetlen összefüggés az iskolai végzettség és a munkanélküliség között, mert például Kassán és Nyitrán is van egyetem, mégis magas a munkanélküliek aránya, különösen a fiatalok körében.

A rendelkezésre álló adatok szerint Szlovákiában is hasonló helyzet van az iskolázottság térbeli megoszlását tekintve, mint Magyarországon. Az iskolavárosok hagyományosan jelentős szerepe a képzésben, valamint az iparosítás foglalkoztatási igényeihez igazodó képzettségi szintek térbeli megoszlása együtt adja mindkét ország képzettségi mintázatát (Mezei 2000).

A foglalkoztatottakon belül vizsgálva a képzettségi adatokat szembetünik Pozsony kiemelkedő helyzete, mert a dolgozók negyedének van felsőfokú, és 43\%-ának középfokú végzettsége (5. táblázat). Ez az országos átlag kétszerese. Habár ilyen magas felsőfokú végzettségi arányt nem tud más megye felmutatni, a fejlesztések szempontjából biztató, hogy a keleti megyékben a középfokú végzettségủek aránya mindenütt $40 \%$ feletti.

\section{TÁBLÁZAT}

A foglalkoztatottak képzettségi szintje 1999-ben(\%)

(The Education Level of Employment in 1999)

\begin{tabular}{lccccc}
\hline \multicolumn{1}{c}{ Megyék } & $\begin{array}{c}\text { A foglalkoz- } \\
\text { tatottak szá- } \\
\text { ma(ezer fö) }\end{array}$ & $\begin{array}{c}\text { Alapiskola } \\
\text { vagy } \\
\text { iskolázatlan }\end{array}$ & $\begin{array}{c}\text { Alsó } \\
\text { középfok }\end{array}$ & $\begin{array}{c}\text { Felsö } \\
\text { középfok }\end{array}$ & Felsöfok \\
\hline Pozsony & 309,2 & 6,0 & 25,1 & 43,0 & 25,9 \\
Nagyszombat & 229,8 & 10,4 & 47,0 & 33,3 & 9,2 \\
Trencsén & 252,4 & 7,9 & 43,3 & 38,9 & 9,9 \\
Nyitra & 266,9 & 11,7 & 46,0 & 34,8 & 7,5 \\
Zsolna & 275,1 & 8,8 & 41,9 & 40,0 & 9,4 \\
Besztercebá- & 246,2 & 6,9 & 36,9 & 44,6 & 11,7 \\
nya & & & & & \\
Eperjes & 285,9 & 5,4 & 44,1 & 40,7 & 9,8 \\
Kassa & 266,9 & 7,3 & 40,7 & 43,0 & 9,1 \\
Szlovákia & 2132,1 & 8,0 & 40,3 & 39,9 & 11,9 \\
\hline
\end{tabular}

Forrás: Regional Comparison in the SR. Statistical Office of the SR. 1999.

A helyzet ellentmondásosságát jól mutatja, hogy az egyébként fejlettebb, kisebb munkanélküliségi mutatókkal rendelkezỏ nyugati megyékben viszont mind az alacsonyabb iskolai végzettségủek, mind a középfokú végzettségüek aránya nagy. Lehet, hogy e mögött van egy belső migráció, azaz „,keleten képződnek, nyugaton dolgoznak" az aktív korúak. Ezt támasztja alá az az adat is, hogy a felső középfokú iskolák nagyobb számban vannak Kassa és Eperjes megyékben, de itt a fiatalok 
száma is magasabb, és fordítva, kevesebb az iskola és a fiatal Nagyszombat megyében (Document 2001, 142).

A területi különbségek fontos mutatója a szociális segélyben részesülök száma és aránya. Kassa megyében volt 1999-ben ez az arány a legmagasabb, az itt lakók 17,6\%-a részesült ilyen ellátásban (6. táblázat). Ez azonban nemcsak helyileg magas arány, hanem országosan is, mert a teljes népesség segélyezettjeinek 23\%-át adják az itt élő hátrányos helyzetủek.

6. TÁBLÁZAT

A segélyezettek aránya a megyék népességében

(The Rate of Beneficiaries in the Population by Counties)

\begin{tabular}{lcc}
\hline \multicolumn{1}{c}{ Megyék } & 1997 & 1999 \\
\hline Pozsony & 1,51 & 2,1 \\
Nagyszombat & 5,34 & 7,5 \\
Trencsén & 3,61 & 6,8 \\
Nyitra & 7,63 & 10,6 \\
Zsolna & 5,32 & 9,3 \\
Besztercebánya & 9,43 & 13,5 \\
Eperjes & 10,57 & 15,9 \\
Kassa & 12,62 & 17,6 \\
\hline
\end{tabular}

Forrás: Document 2001, 155.

Az arányok minden megyében jelentősen nőttek, Trencsénben majdnem megduplázódtak. Ennek egyrészt oka lehet az országosan jelentősen növekvő munkanélküliség, másrészt az, hogy az ország, gazdasági megerösödésének arányában, többet tud áldozni a rászorulók támogatására. Másrészt a 6 . táblázat megerösíti a keleti és a déli megyék súlyos helyzetét. Nyitra megyének a déli, határ mentén fekvő járăsaiban vannak súlyos nehézségek.

7. TÁBLÁZAT

A legszegényebb járások sorrendje a segélyezettek alapján

(The Order of the Poorest Districts by Beneficiaries)

\begin{tabular}{clcc}
\hline \multirow{2}{*}{ Sorrend } & Járások & $\begin{array}{c}\text { A segélyezettek } \\
\text { száma } \\
(\text { fö })\end{array}$ & $\begin{array}{c}\text { A segélyezettek } \\
\text { aránya a járás } \\
\text { népességében }(\%)\end{array}$ \\
\hline 1 & Rimaszombat & 9587 & 26,3 \\
2 & Nagyröce & 4666 & 25,5 \\
3 & Töketerebes & 11364 & 24,6 \\
4 & Kézsmárk & 5367 & 23,9 \\
5 & Rozsnyó & 6763 & 23,6 \\
6 & Kisszeben & 4419 & 22,2 \\
7 & Gölnicbánya & 2670 & 21,6 \\
8 & Igló & 7644 & 21,0 \\
9 & Varranó & 6324 & 20,3 \\
\hline
\end{tabular}

Forrás: Document 2001, 156. 
A járások sorrendjét tartalmazó adatokból világosan látszik (7. táblázat), hogy a keleti és a déli megyék több járása küzd hátrányos helyzettel, és közülük különösen a déli járások vannak rossz helyzetben. Velük szemben áll Pozsony öt, járásnak minősített kerülete, ahol 1 és $2 \%$ közötti arányokban vannak csak segélyezettek.

Az utak hossza és különösen minősége, valamint a kommunális ellátás szoros összefüggésben van a megye általános fejlettségével (8. táblázat). A keleti és déli megyék útellátottsága alacsony fokú, a vasúthálózat jelenleg folyó racionalizálása, azaz csőkkentése föleg ezeket a területeket érinti. A vízellátás $80 \%$ alatti aránya a megyén belüli ellátási különbségekre utal, hiszen a vezetékes víz hiánya minden bizonnyal a falusi (déli, határ menti) falvakat érinti. A csatornázottság foka - Pozsony kivételével - fele a vezetékes vízzel való ellátottságnak. Ennek az ollónak a nyitottsága a környezet védelme szempontjából rendkívül káros, a különbség csökkentése viszont igen komoly beruházásokat igényel (csatornázás, víztisztítás stb.).

\section{TÁBLÁZAT}

Ủt, vízellátás és csatornázottság 1999-ben

(Road, Water-supply and Sewer System in 1999)

\begin{tabular}{lcccc}
\hline \multicolumn{1}{c}{ Megyék } & $\begin{array}{c}\text { Utak } \\
\text { hossza } \\
(\mathrm{km})\end{array}$ & $\begin{array}{c}\text { Magasabb } \\
\text { rendü utak } \\
\text { aránya }(\%)\end{array}$ & $\begin{array}{c}\text { Vezetékes } \\
\text { vizzel ellátott } \\
\text { népesség(\%) }\end{array}$ & $\begin{array}{c}\text { Csatomával } \\
\text { ellátott népesség } \\
(\%)\end{array}$ \\
\hline Pozsony & 799,5 & 29,11 & 94,5 & 82,2 \\
Nagyszombat & 1946,7 & 17,90 & 82,2 & 44,6 \\
Trencsén & 1856,7 & 19,63 & 84,4 & 52,7 \\
Nyitra & 2552,6 & 20,14 & 81,9 & 45,2 \\
Zsolna & 1967,3 & 26,11 & 84,1 & 48,7 \\
Besztercebánya & 3158,7 & 18,18 & 82,3 & 56,8 \\
Eperjes & 3079,6 & 19,25 & 75,0 & 51,5 \\
Kassa & 2372,8 & 15,71 & 77,0 & 57,3 \\
\hline
\end{tabular}

Forrás: Szlovák Statisztikai Hivatal 2001.

\section{Területi különbségek a déli járásokban}

A déli határ mentén 13 járás található, ezek a következők: Pozsony V., Szenec (Senec), Dunaszerdahely (Dunajska Streda), Komarno (Komárom), Érsekújvár (Nove Zamky), Léva (Levice), Nagykürtös (Velky Krtis), Losonc (Lucenec), Rimaszombat (Rimavska Sobota), Nagyröce (Revuca), Rozsnyó (Roznava), Kassa-vidék (Kosice-okolie), Töketerebes (Trebisov).

A déli járások gazdasági állapotát Tuba Lajos kutatásai alapján mutatjuk be (Tuba 2000). Ez a határsáv mezógazdasági terület volt a múltban, sőt a kommunizmus évtizedeiben Csehszlovákia éléstárának számított, ennek megfelelóen nem is törekedtek iparosítani olyan mértékben, mint az ország többi részét. Dél-Szlovákia keleti részén viszont Kassán és környékén olyan, katonai szempontból fontos építkezések voltak, valamint olyan energia-szállító vezetékrendszerek haladtak, ame- 
lyeknek a stratégiai fontossága miatt egyéb építkezéseket nem engedélyeztek. Mindez a térség lemaradását jelentette.

Az 1990 óta zajló átalakulás modernizációja nem volt eddig elég gyors ahhoz, hogy látványos eredményekről lehessen beszámolni. Különösen a mezőgazdaság kerültt válságos helyzetbe a világpiachoz való kapcsolódással. Az új köruilményekhez alkalmazkodva sok kisvállalkozás jött létre, de a tökeszegénység és a hagyományok híján jobbára kereskedelmi tevékenységet folytatnak. A rohamosan szaporodó nemzetközi nagykereskedelmi üzletláncok világában az ő idejuk is lejár. Az élelmiszeripari üzemek többsége is a túlélésért küzd, hiszen a külföldröl behozott áruk versenyével nehezen tudnak megbirkózni. Ezekben a járásokban a legnagyobb munkaadóvá fokozatosan a külföldi tulajdonban lévő alkatrészgyártó bedolgozó üzemek váltak.

Az idegenforgalom a párkányi, az érsekújvári és a tardoskeddi gyógyfürdökre épüil. A párkányi Mária Valéria-hídtól is a vendégforgalom növekedését várják. A déli határ mentén található, föleg a keleti piacokra termelỏ kisebb (könnyüipari) üzemek többsége is tönkrement. A mohi atomerómü építkezése, illetve múködtetése adott munkahelyeket. A Nagykürtös környéki és a rozsnyói barnaszénbányákat a gazdaságtalan termelés miatt zárták be. A kassai vasmủ, az 1990-es csőd közeli helyzet után jelentős állami támogatást kapott, majd néhány kétséges privatizációs akció után mára amerikai tulajdonba került. Azóta helyzete stabilizálódott. A legrosszabb helyzetben a legkeletibb járások vannak, amelyek gazdaságát a szovjet külkapcsolatokra építették. Ezek az üzemek azonban mind csődbe mentek, helyüket még nem tudták újakkal helyettesíteni.

Mindezek miatt érthető, hogy a munkanélküliség szempontjából az egész déli országrészben kedvezőtlen a helyzet. Éppúgy, mint a lakosság természetes létszámcsökkenése alapján, a munkanélküliségi arány szempontjából is összefüggö válságövezet mutatható ki Révkomáromtól egészen Tőketerebesig. A munkanélküliségi „ranglétra” elsö öt helyén déli járás szerepel (Rimaszombat, Tőketerebes, Nagykürtös, Nagyröce, Rozsnyó), de Szencen kívül az összes többi déli jårásban is az országos átlagnál magasabb a munkanélkuiliség.

Ez szorosan összefügg a déli régió lakosainak iskolázottságával. Elsősorban a rimaszombati, a nagykürtösi, a rozsnyói és a töketerebesi járásban nagyon alacsony a lakosság müveltségi szintje. A müveltség problémája a nyugat-szlovákiai régiók vegyesen lakott területein is megmutatkozik, ami tobbek közt azoknak a kormányoknak is köszönhetö, amelyek a nem szlovák lakosság számára nem teremtettek lehetőséget a magasabb szintủ múveltség megszerzésére. Ezt látszik bizonyítani az a tény is, hogy a nagyszombati kerület járásai közül az iskolázottsági szintet tekintve a galántai és a dunaszerdahelyi járás van az utolsó helyen, a nyitrai járásban a lévai, az érsekújvári, a révkomáromi és a vágsellyei járás lakossága a legalacsonyabban iskolázott. Ugyanilyen helyet foglal el a besztercebányai kerületben a losonci, a nagyrỏcei, a rimaszombati és a nagykürtösi járás. A kassai kerületben a Kassa környéki, a rozsnyói és a tőketerebesi járás van hasonló helyzetben. 
A déli járások gazdasági potenciálját az ipari termelés forgalmából, a hozzáadott értékböl és a jövedelemadóból kiindulva hasonlíthatjuk össze. Az ipari termelés ezer lakosra számított forgalmát tekintve a déli régiók az országos átlag alatt vannak, kivéve a nagymihályi, a vágsellyei és a lévai járást, ahol nagyobb arányú ipari termelés összpontosul. Különösen alacsony értékeket mutat a tőketerebesi, a nagykürtösi, a szenci és a dunaszerdahelyi járás, ami egyrészt a régiók mezőgazdasági jellegével, másrészt a nagy ipari központok - Pozsony, Kassa - árnyékával magyarázható.

A másik gazdasági mutató a hozzáadott érték, ami a gazdasági össztermelés és a köztes felhasználás különbségét jelöli, és utal a régióban kitermelt termékek és szolgáltatások hasznosítására. Ilyen szempontból a legmagasabb értéket a lévai és a vágsellyei járásban mutatták ki, míg a dunaszerdahelyi, a tőketerebesi, a Kassa környéki, a rimaszombati, a nagykürtösi, és az érsekújvári járás mutatói a legalacsonyabbak az országban. Ebböl a szempontból az egyes kerületeken belül is nagyon eltérőek az értékek. Például a nagyszombati kerületben a szakolcai, a nagyszombati és a galgóci járás nagyon pozitív értékeket mutat, míg a dunaszerdahelyi és a galántai a hozzáadott érték és az ipari termelés forgalma szempontjából is nagyon alacsony értékekkel jellemezhetö.

A déli járások mezőgazdasági jellege a lakosok jövedelmének nagyságában is megmutatkozik. Míg 2000-ben a szlovákiai átlagkereset 9815 korona volt, a dunaszerdahelyi járásban 8094, a galántaiban 8175 , a komáromiban 7982, a losonciban 7916 , a rimaszombatiban 7928 , a nagykürtösiben mindössze 7663 , a Kassa környékiben 8424 , a tỏketerebesiben pedig 7545 korona volt. Ami a jövedelemadót illeti, az e mutató szerint felállított sorrend alapjában véve megegyezik a ipari termelés forgalma szerinti sorrenddel. A szenci, a vágsellyei és a lévai járást kivéve az összes többi déli járás a leggyengébbek közé tartozik, s ezek között is a keleti járások gyengébbek a nyugatiaknál. A vágsellyei és a lévai járás jobb eredményei is csak annak köszönhetőek, hogy itt országos jelentőségủ ipari létesítmények vannak, mégpedig a vágsellyei Duslo vegyi üzem és a mohi atomerömü.

Ha az egyes kerületek járásait akarjuk összehasonlítani, a nagyszombati kerületben mindkét mutató - vagyis a bérek és a jövedelemadó - szerint is a dunaszerdahelyi és a galántai járás van az utolsó helyen. A nyitrai kerületben Révkomárom van az utolsó helyen, de Érsekújvár és Nagytapolcsány is átlagon aluli értékeket mutat. A besztercebányai kerület déli járásai közül a nagýkürtösi mutat állandó jelleggel alacsony értékeket. A kassai kerületben a tőketerebesi, a szobránci és a gölnitzi járás mutatja a leggyengébb eredményeket.

Ha az egyes régiók gazdasági erejét a tőkebeáramlás szerint vizsgálnánk, ebből a szempontból a leggyengébbnek az északkeleti és az északnyugati régiók mutatkoznak. A déli járások közül a legrosszabb eredményeket a nagyrőcei, a tőketerebesi, a rimaszombati, a losonci, a Kassa környéki és a nagykürtösi járás mutatja. Érdekes, hogy a délnyugati régióból csupán a lévai, az érsekújvári és a bazini járás szerepel a leggyengébbek között. 
Járási szinten a népesség fejlődését befolyásolja a gazdasági eszközök, a családok gazdasági helyzetének alakulása, valamint a népesség életkorbeli összetétele. A természetes népességnövekedés csökkenése, valamint az egyre gyakoribb bevándorlás a déli régió nemzetiségi összetételének megváltozását idézheti elö. A déli területek átlagon felüli munkanélküliségi aránya tulajdonképpen a rendszerváltás óta jellemzö. Ezt egyrészt az okozza, hogy az itteni elavult ipari létesítmények képtelenek voltak lépést tartani a modern piaci követelményekkel, másrészt a bányászati és a mezőgazdasági termelés leépülése, a lakosság alacsony mủveltségi szintje, valamint a határ menti járások elégtelen infrastruktúrája is szerepet játszott (Gaál 2000).

\section{Kiemelt példa: a rimaszombati járás}

A fentieket jól érzékelteti egy járás közelebbi bemutatása (BartakovicRittenbacher-Rabely-Tóth 2000). A rimaszombati járás $74 \mathrm{~km}$ hosszan határos Magyarországgal, a besztercebányai kerület része. Maga a járás Szlovákia egyik legnagyobb járása a maga $1471 \mathrm{~km}^{2}$-ével. A járásban összesen 107 település van, közülüik három város. Rimaszombat (Rimavska Sobota) 25070 fövel, Nyustya (Hnúst'a) 4430 fővel és Tiszolc (Tisovec) 4430 fövel. A járás aprófalvas körzetnek számít, mert a 104 községből csak kettőnek van több mint kétezer lakosa (Klenóc/Klenovec: 3470 fö, Feled/Jesenské 2150 fö), a többiben átlagosan 430 fö él.

A régi Gömör-Kishont megye érckészleteinek és erdeinek köszönhetöen itt volt a korabeli Magyarország egyik legjelentősebb bányászati és vasfeldolgozó központja. Az 1860-as évektöl a nyersvasat és az öntvényeket 26 nagyolvasztóban állították elö (Nyustya, Tiszolc). A legismertebb cégek a Koburg, a Blasberg és a Rimamurányi-Salgótarjáni Részvénytársaság voltak. A térség központja Rimaszombat város volt, Gömör megye élelmiszeripari, kézmüves és kereskedelmi centruma. A déli területeken nagybirtokos mezőgazdaság folyt. A gazdasági kapcsolatok Salgótarján és Putnok felé irányultak elsősorban.

A két világháború között a járás Csehszlovákia gazdasági életében már nem játszott jelentős szerepet, megkezdődött az elszegényedése. Az eddigi észak-déli kapcsolatokat ugyanis nem váltotta fel az új politikai helyzetben életbevágóan szükséges kelet-nyugati (Pozsony-Kassa) kapcsolat, jelesül akkor nem épült meg a két várost összekötő vasúti és közúti összeköttetés. A természetes észak-déli kötődés felszámolása a területet perifériára sodorta.

A második világháború után sem indult el igazán e területek fejlesztése. 1945 után fejlödött a bányászat (zsírkö, mészkö, magnezit), a vegyi-, a gép- és a feldolgozóipar. Rimaszombaton élelmiszeripari komplexum épült (cukorgyár, sörgyár, konzervgyár, húsüzem, borüzem). Azonban a mezögazdaság mindig is jelentösebb volt, a járásban a munkaképes lakosság 33\%-át foglalkoztatta 1991-ben. A dinamikus fejlödés gátja az volt, hogy a folyamatos cseh-szlovák nacionalizmus (egymást is kijátszva) a fejlesztések nagy részét elsösorban a cseh területekre koncentrálta, 
illetve a szlovákiai fejlesztések nagy részét (pl. az élelmiszeripari feldolgozó üzemeket) északabbra, a szlovákok által lakott vidékekre telepítette.

A járásban található Szlovákia legnagyobb zsírkő készlete, itt egyúttal magnezit és dolomit is található, Tiszolcon pedig nagy mennyiségü mészkő.

A járásban 82106 lakos él, melynek fele (51\%) szlovák, 44,6\%-a magyar, 3,4\%-a cigány és 1,8\%-a más nemzetiségủ (cseh, román, ukrán). Az utolsó 15 év jellemzője az volt, hogy a szlovák és a magyar lakosok száma erösen csökkent az alacsony népszaporulat és az elvándorlás miatt, miközben a cigány lakosok aránya magas szaporulatuk következtében jelentősen emelkedett. Az utolsó népszámlálás alkalmából csak 3,4\% vallotta magát cigánynak, de valós részarányuk 1998-ban 19-20\% körül volt a becslések szerint.

A foglalkoztatottság területén 1989-hez képest jelentős romlás tapasztalható. Az akkor foglalkoztatott 42469 föhöz képest 1998-ban csak 13568 föt foglalkoztattak. A munkanélküliséget tekintve a járás az országon belül a legrosszabbak közé tartozik, 1999-ben az arány 35,3\%-os volt. A legnagyobb mértékben itt is az alacsony iskolai végzettségúeket sújtja a munkanélküliség $(44,1 \%)$. Köztük is a legkilátástalanabb helyzetben a cigányok vannak. Jelentős részük soha nem dolgozott, iskolai végzettségük nagyon alacsony, nem keresett munkaerő. A munkanélküliek 14791 fős seregén belül a cigányok száma 5664 fö, ez 38,29\%-nak felel meg. A munkanélküliség elsősorban a határ menti településeket sújtja, itt némely településen a cigányok aránya a 70\%-ot is meghaladja.

A járás infrastrukturális helyzete is a szlovák átlag alatt van. Az áramellátás kielégítö, de a gázellátás még kiépítetlen. A 107 községböl csak 30-ban van vezetékes gáz. A vízellátás is megoldatlan, csak 53 községben van vízvezetékrendszer. A csatornázottság szintje még ennél is rosszabb, mert a három városon kívül csak hat községben van, de a szennyvíztisztítás csak két városban és három községben megoldott.

A járásnak terjedelmes úthálózata van, de csak $48 \mathrm{~km}$ első osztályú belőle. A vasúthálózat 47 km hosszú, egy szárnyvonal Bánrévén keresztül kapcsolódik Egerhez. A telekommunikációs rendszer fejlett, többségében digitális rendszerú, optikai kábelek keresztezik a járást kelet-nyugat, észak-dél irányban.

A térség gazdaságára a stagnálás a jellemző. A legtöbb embert foglalkoztató ágazat a járás déli részeit jellemző, kevés jövedelmet adó mezőgazdaság. Az ágazat válságát jól mutatja, hogy a növénytermesztés jelentősen kisebb területre szorult vissza, az állatállomány csökkent a gazdaságtalan tartás miatt. A birtokstruktúra elaprózódott, sok kistulajdonos kezébe kerültek a földek.

Az ipari üzemek a járás északi részein találhatók, ezeket azonban a tökeszegénység jellemzi, alig van külföldi vállalkozás a térségben. A privatizáció hatására részvénytársaságok és korlátolt felelősségủ társaságok alakultak. Az ipari vállalkozások közül az élelmiszeripar foglalkoztatja a munkavállalók $42 \%$-át. Az élelmiszeripar túlsúlyát jól érzékelteti, hogy a bruttó ipari termelésböl 1989-ben 39\%-kal részesedett, 1996-ban pedig már $65,2 \%-k a l$. Az ipar leépullésében az is közrejátszott, hogy az üzemek köz- 
pontjai nem a járás területén voltak. Emiatt nem jutottak fejlesztési forrásokhoz, illetve önállósodásuk után nem rendelkeztek a szükséges szakemberállománnyal.

A turizmus fejletlen a terület természeti szépségei ellenére. Az okok között a közlekedési nehézségeket is meg kell említeni, mert pl. Magyarország felől két távoli határátkelörỏl jöhetnének a kirándulók, de a nagy távolság miatt ez a járás kiesik a turisztikai célpontok közül. Emiatt kihasználatlanok nyáron a vízisport lehetőségek, télen a síterepek.

Ezt a sokféle ellentmondást a területfejlesztés intézményrendszere próbálja oldani, de hatásos eredményekről még nem beszélhetük, mert a rendszer most van kiépülöben.

\section{A területfejlesztés intézményrendszere Szlovákiában}

\section{Az intézményi területfejlesztés kialakulása}

1990 az új területi politika kezdő dátuma Csehszlovákiában. A regionális gazdaságpolitika alapelveit egy 199l-es rendelettel alkalmazta először a csehszlovák kormány. Ezek az elöírások megfeleltek az európai tervezési kartában lefektetett alapelveknek. Ekkor jöttek létre a regionális fejlesztés első intézményei is, mint a Stratégiai Tanulmányok Központja, a Társadalom, Tudomány és Technológia Fejlesztési Stratégiájának Hivatala. Azokban a járásokban, ahol a munkanélküliség $20 \%$ fölötti volt, a szakszervezetekkel (!) kötött szerződés értelmében fejlesztési ügynökségeket hoztak létre. 1997-ben a kormány elfogadta az állami területpolitika koncepcióját, valamint kidolgoztatott egy sor dokumentumot a határon átnyúló és a nemzetközi együttmủködésekröl, az uniós integrációról. 1999-ben a kormány jóváhagyta a Területi és társadalmi fejlesztés integrált tervét, amely 29 hátrányos helyzetủ járásra vonatkozott. Ezek a kassai, az eperjesi és a besztercebányai régiókban voltak.

Szlovákiában az Épitésügyi és Területfejlesztési Minisztérium a területi politika szervezó intézménye, amely kidolgozza az általános szervezeti és intézményi kereteket, biztosítja a területi fejlesztéshez a programokat és a forrásokat. 2000-ben fogadta el a kormány a regionális politika alapelveit, amely elöírja, hogy a kormány miniszterei és más központi szervek elnökei a szlovák regionális politika elvei alapján cselekedjenek. Ez biztosítja a területfejlesztés támogatásának komplex rendszerét.

$\mathrm{Az}$ állami területpolitika azokat a régiókat támogatja, amelyek a következő feltételeknek felelnek meg:

- Gazdaságilag hátrányos helyzetü régiók, amelyek a gazdasági és társadalmi fejlődést tartalmazó jelzőszámok szerint az országos átlag alatt vannak. Ilyen mutatók a népsủrủség, a munkanélkül iség, a jövedelmek nagysága, a gazdasági ágazatokban foglalkoztatottak aránya, a helyi költségvetések adóbevétele.

- A strukturális válsággal küzdö régiók, ahol a gazdasági szerkezetváltás okozott negatív hatásokat. 
A regionális politika legfontosabb dokumentuma a Nemzeti Területfejlesztési Terv. Ez középtávú programokat tartalmaz, amelyek megfogalmazzák a regionális fejlesztés stratégiáját, meghatározzák a szükséges forrásokat és fejlesztési elveket, a fejlesztési programok kidolgozásához szükséges tárgyakat és fontossági sorrendeket. A Nemzeti Fejlesztési Terv egy része ágazati programokat tartalmaz. A terv kidolgozása és kormányzati jóváhagyása az építésulgyi és területfejlesztési minisztérium felelösségébe tartozik.

A régiófejlesztési koncepciók középtávú elemzéseket és terveket tartalmazó dokumentumok, amelyek az egyes régiók fejlesztésének az elveit és a megvalósítás sorrendjeit tartalmazzák, egyúttal végrehajtási programok kidolgozásának alapjául is szolgálnak.

A településfejlesztési programok célja, hogy a helyi közösségek érdekeit egyeztessék a gazdasági és szervezeti egységek kezdeményezéseivel. Az egyes települési önkormányzatok felelősségi körébe tartozik ezeknek a programoknak a kidolgozása (NPRD 2001, 50-51).

A szlovák területfejlesztési rendszerre rányomja bélyegét, hogy a fiatal, 1993 óta létezỏ állam fennállásának elsỏ szakaszában erös, nacionalista vezetés alatt állt. A politikai folyamatokból következően erösen centralizált területi irányítási rendszert vezettek be. Csak a települések (városok/községek) szintjén létezett (erősen korlátozott) önkormányzatiság, a magasabb területi szinteken (járás, körzet) állami hivatalok birtokolták az irányítást. 2002 óta a megyék új jogállást kaptak, az európai szokásoknak megfelelöen a középszint is ơnkormányzati rendszerủvé vált. A feladatok átadása a megyei hivataloktól a megyei önkormányzatok számára most is folyamatban van, ez maga után fogja vonni a területfejlesztés intézményrendszerének, a területi szintnek a változását is.

\section{A területfejlesztés szintjei}

\section{Központi szint}

A területfejlesztés intézményesülését (9. táblázat) mutatja, hogy a szlovák kormány felelösséget vállal az ország fejlesztési politikájáért. Jóváhagyja a szükséges dokumentumokat, elöterjeszti a törvényjavaslatokat a parlamentben, javasolja a pénzügyi források elkülönítését a költségvetésben. Létrehozta a területfejlesztési politika tanácsát, amely ágazatok feletti szervezési és kezdeményezési jogosítványokkal bír. A kormányhivatalon belül a területfejlesztési osztály látja el az említett tanács titkársági feladatait. Törvényességi, szervezési és szolgáltatási tevékenységét a miniszterelnök-helyettesi rangban lévő emberjogi, kisebbségi és területfejlesztési feladatokat ellátó miniszter felügyeli. 
A területfejlesztés közvetlenül az Építésügyi és Területfejlesztési Minisztérium hatáskörébe tartozik.

- Egyezteti az állami hivatalok és a területi önkormányzati szervek testületeinek tevékenységét, beleértve a nemzeti fejlesztési terv, valamint a területi és ágazati végrehajtási programok előkészítését és végrehajtását.

- Kidolgozza az állami és területi önkormányzati szervekkel, valamint a társadalmi és gazdasági partnerekkel a nemzeti fejlesztési terv feladatait, és átadja a kormánynak jóváhagyásra.

- Biztosítja a területi végrehajtási programok kidolgozását a minisztérium különbỏzô osztályainak segítségével, együttmüködve a fent említett szervezetekkel.

- Értékeli a nemzeti fejlesztési terv és a teriileti végrehajtísi programok teljesítését.

- Biztosítja az együttmüködést az Európai Unió testuileteivel, ellenőrzi a különféle (a gazdasági és társadalmi kohéziót, valamint a nemzetközi és a határon átnyúló együttmủködések támogatását célul kitüző) alapokból származó pénzügyi források hasznosítását.

- Hivatalain keresztül biztosítja a pályázatok kiválasztását a területi végrehajtási programok teljesítésére, együttmüködve más állani testületekkel a független szakértői értékelések elkészítésében.

- Létrehozza a Területfejlesztési Ügynökséget (végrehajtási és pénzügyi jogkörökkel), a területi ellenórzö bizottságokat és a Nemzeti Ellenőrző Bizottságot. A müködésükhöz szükséges alapvetó dokumentumokat a különböző hivatalok készítik el.

Mivel a területfejlesztés több ágazat együttmủködését igényli, más minisztériumok és más központi szervek is részt vesznek több-kevesebb feladat átvállalásával.

- A Pénzügyminisztérium szerepe a legerösebb, mert a pénzügyi feltételeket biztosítja az elócsatlakozási, késóbb pedig a strukturális alapok társfinanszírozásával, felelős a PHARE, az ISPA és a SAPARD programok pénzügyi megvalósításáért.

- A Környezetvédelmi Minisztérium az ISPA-programot,

- a Mezőgazdasági Minisztérium az agrárpolitikát, a vidékfejlesztést és a SAPARD programot kezeli,

- a Közlekedési, posta és távközlési Minisztérium az ISPA-t.

- A Gazdasági Minisztérium az iparpolitikán kívül a turizmussal, a külföldi befektetőkkel, a kis- és középvállalkozások támogatásával foglalkozik.

- A Munka- és családügyi Minisztérium a foglalkoztatási politikával,

- a Belügyminisztérium a helyi állami adminisztráció határon átnyúló és nemzetközi kapcsolataival a területfejlesztésben,

- a Külügyminisztérium a területpolitika nemzetközi kapcsolataival,

- a Kulturális Minisztérium a kulturális örökség védelmével és fejlesztésével, valamint a szlovák régiók kulturális értékeinek hasznosításával foglalkozik. 
Mezei István - Hardi Tamás:

A szlovák közigazgatás és területfejlesztés aszimmetriái.

Tér és Társadalom, 17. 2003. 4. 127-155. p.

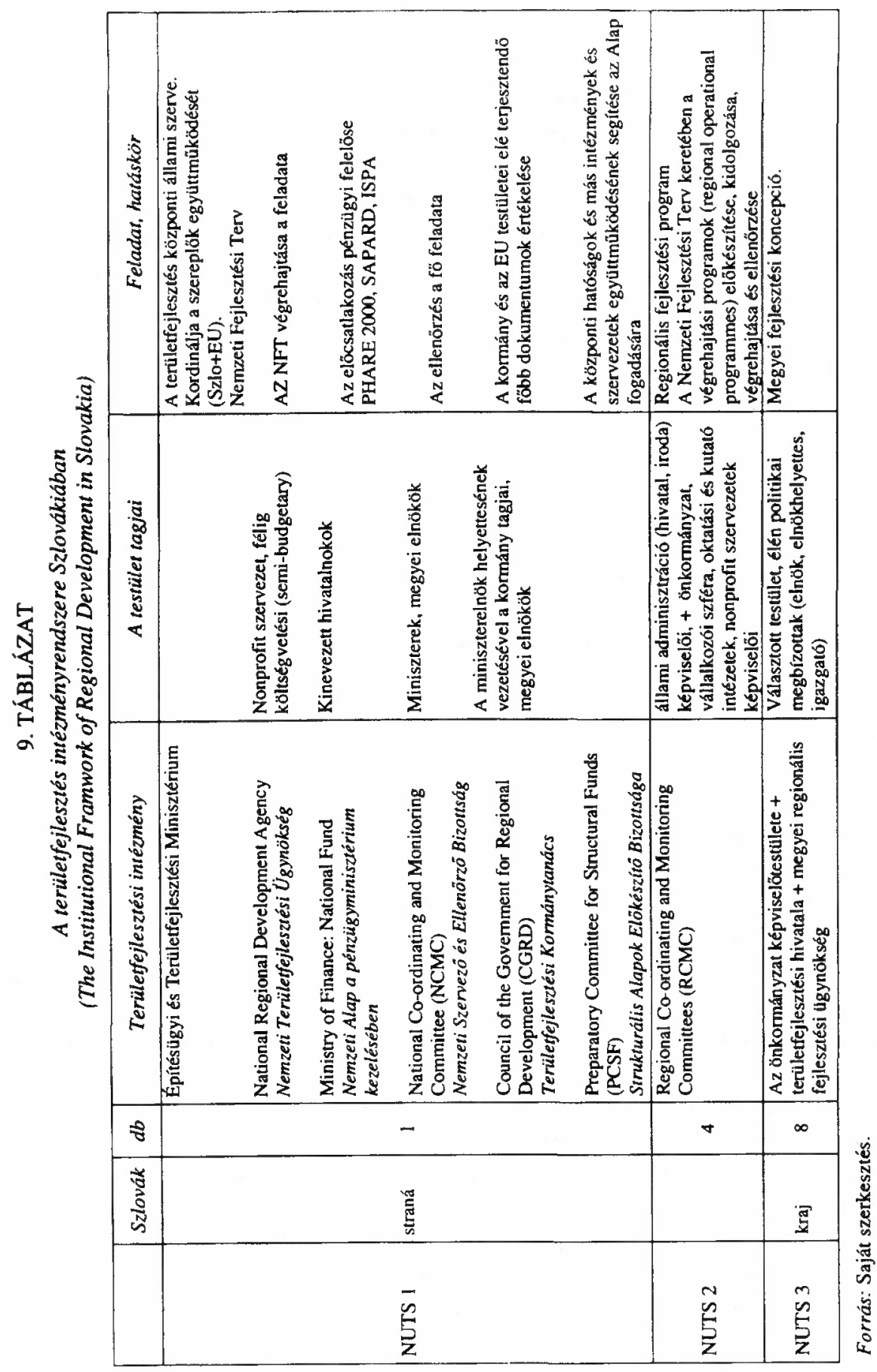




\section{Középszint}

A középszintnek egymás mellett több szerve is működött Szlovákiában. A rendszerváltást követően, a közigazgatás módosításával az államigazgatási kerület és a járás volt a területfejlesztés intézményi biztosítéka 2001 decemberéig. Ezek mindegyike a belügyminiszter alá rendelve hajtotta végre a minisztériumok rendelkezéseit, tehát a központi szervek megyei és járási szinten működő hivatalai voltak.

A megyei hivatalok kidolgozták és jóváhagyták a megyei fejlesztési koncepciót, részt vettek a megyei végrehajtási programok kidolgozásában, biztosították azok megvalósítását, együttmúködtek az állami hivatalok központi testületeivel a megyei fejlesztés feladatainak végrehajtásában, a fejlesztésben érintett valamennyi szervezet együttmúködését koordinálták, együttmủködtek a munkaügyi hivatalokkal.

A járási hivatalok részleges feladatokat teljesítettek, a járásuk területén folyó fejlesztési folyamatokkal összhangban. Ök voltak közvetlenül kötelezve, hogy gondoskodjanak az igényelt segítségröl a nemzeti fejlesztési terv elökészítése és végrehajtása során a minisztérium vagy a megyei hivatal kérésére. Mivel az elkészuilt tervek inkább az infrastruktúra fejlesztését szolgálták, inkább nevezhetnénk ezt a tevékenységet területrendezésnek.

Mivel 1990 óta érvényben volt az önkormányzati törvény, lehetösége volt a településeknek arra, hogy önként vállaljanak közszolgáltatási feladatokat. Ezzel a lehetőséggel élve egyes városok, amelyektöl az 1996-os közigazgatási reform során elvették a járási jogköröket, önként vállaltak ilyen feladatokat. A kialakított (megtartott) hivatali környezetvédelmi és regionális osztály felmérte az igényeket, a lehetőségeket. Az ehhez szükséges adatokat a közigazgatási osztály szolgáltatta, mert az rendelkezik részben a lakossági, részben a gazdasági-vállalkozói szféra adataival $^{2}$. Az elkészuilt javaslatokból az építésügyi osztály készített terveket és a pénzügyi osztály biztosította az anyagi fedezetet. Ezzel az eljárással történt több település víz- és gázellátásának, hulladékgazdálkodásának a megoldása.

Ez az eljárási rend nélkülözi a helyi erők bevonását, mert a képviselőtestület is csak tájékoztatást kap az elvégzendő munkákról, illetve elvi beleegyezését adja, hogy hozzájárul a fejlesztési feladatok vállalásához, és megbízza a hivatal illetékes osztályait az ügy, az ügyek elrendezésével. Innentöl kezdve a hivatali apparátus dolga lett a tervezés és a végrehajtás. A hivatal a pályázatok elkészítésétöl kezdve azok beadásáig, sőt a végrehajtásig mindent elintéz. A pályázatok kiírása, elbírálása az illetékes minisztériumban történik, a nyertes pályázatok pénzügyi fedezetét pedig a Pénzügyminisztérium biztosítja.

Ennek a rendszernek az is a sajátossága, hogy ágazati beruházásokról van szó, nem komplex területfejlesztésröl. Az egyes minisztériumok által kiírt pályázatok adtak lehetöséget a fejlesztésekhez, de ha valamely minisztérium nem aktivizálódott, akkor onnan nem érkeztek források a fejlesztésre. Ilyen hátrányos helyzet alakult ki a mezőgazdaságban a minisztérium passzivitása miatt. Mivel az önkormányzati önállóság, segítőkészség nincs minden városban, járási központban ilyen 
erős formában jelen, általánosabb volt, hogy a minisztériumi kiírásokra a falvak maguk készítették el a pályázatokat, amit benyújtottak a járási hivatalba előzetes elbírálásra. Ha itt elfogadták, akkor ment tovább a minisztériumba a pályázati anyag, amit érdemes ezek alapján inkább kérvénynek tekintenünk.

A középső szinten változást hozott az Európai Unió 2001-es észrevétele, kifejezetten az ö kérésükre alkották meg a kb. 1,2 milliós lakosságszámú négy régiót NUTS 2 szinten, mert a tervezett nyolc megye támogatásának adminisztrációs feladatait sokallta a brüsszeli központ. Ez a négy régió azonban pusztán statisztikaiadminisztratív szintet jelent, önálló intézménye, titkársága nincs, csak a szükséges fejlesztési dokumentumok összeállítása alkalmával ülnek össze az országos szervek és az egyes érintett megyék képviselöi. Amikor kidolgozták ennek a nagyrégiós szintnek a fejlesztési dokumentumait, akkor a kerületi hivatalok egyes fejlesztési dokumentumait fésülték össze. Elfogadásuk után az itt szereplö célokra lehet az önkormányzatoknak és a kistérségeknek támogatást kapni. Mivel Szlovákia egésze elmaradott területnek számít, egyelöre nincs szükség a nagyrégiók szintjén az intézményrendszer létrehozására. Az országba bejövő támogatásokat a megyei fejlesztési ügynökségek fogják elosztani a hozzájuk pályázó települések és társulások között.

A következő változást a megyei önkormányzati választások hozták 2001 decemberében, mert a területfejlesztés kötelezỏen, alapfeladatként átkerült az állami (kerületi) hivataltól a megyei önkormányzathoz.

A megyei önkormányzatok testületei a szlovák közigazgatás reformja szerint minden rájuk vonatkozó fejlesztési feladatkört megkaptak. Az önkormányzati testület a területfejlesztési osztály segítségével kidolgozza a megye fejlesztési koncepcióját és vállalja a felelösséget a végrehajtásért. Együttmüködik a végrehajtási programok (operatív programok) kidolgozásában és végrehajtásában, ellenörzi és rendszeresen értékeli a megye társadalmi-gazdasági fejlődését, és ezt az értékelést benyújtja a Területfejlesztési Minisztériumnak. Együttmüködik az állami adminisztráció központi testületeivel a területfejlesztés feladataiban, segíti minden érintett szervezet együttmüködését. A járási hivatalok megszủnésével azok feladatköre a megyei önkormányzatok testületeire száll át a tervek szerint.

A fejlesztési dokumentumok létrehozására, a pályázatok kiírására, elbírálására, a beruházások ellenőrzésére, a pénzügyek kezelésére egy külön megyei területfejlesztési ügynökség létrehozására lesz szükség, a szaporodó feladatok és az összeférhetetlenség elkerülése érdekében is. Amíg ez nem valósul meg, addig nemzeti szinten (az ágazati minisztériumokban) döntik el a pályázatok sorsát.

A fent ismertetett rendszer kialakulóban-átalakulóban van. A megyei önkormányzatok most veszik át a feladatokat a kerületi hivataloktól, illetve most kezd formálódni megyei szinten az a fejlesztési ügynökség, amely majd átveszi az ilyen típusú ügyek intézését. A járási szint is változik, meg fog szủnni, de feladatai különbözö szervezetekhez kerülnek. A területfejlesztés feladatköre egyrészt a megyéhez, másrészt a már régóta müködő kistérségi-járási fejlesztési ügynökségekhez fog tartozni. 
A szlovák nyelvhasználatban regionálisnak mondják ezeket a szervezeteket, emiatt rövidítésük RFÜ, szlovákul RRA.

Ezek az ügynökségek - kis számban - már 1990 után létrejöttek, de akkor még erösen kőtődtek az országos (szlovák) politikai szervezetekhez, különösen az ország önállóvá válása után. 1998 óta törekednek arra, hogy függetlenedjenek a politikától, és az elmaradott területek fejlesztésével foglalkozhassanak. Ezt szolgálja az ügynökségek jogi formája is, mert civil egyesületként szerződést köthetnek az állammal bizonyos információs és területfejlesztési feladatok elvégzésére. Az alapításukban magánszemélyek, települési önkormányzatok is részt vesznek. A 2000 körul alakult, területfejlesztéssel foglalkozó ugynökségek kezdetben a kialakulatlan viszonyok miatt pénzügyi segítséget külföldi: holland, brit, amerikai, japán támogatóktól kaptak, mert a szlovák kormány pénzügyi nehézségei miatt nem írt ki fenntartásukra, mủkődtetésükre pályázatokat. Ahol magyarok az ügynökség munkatársai, illetve ahol a településeken magyarok is élnek, ott a magyarországi Új Kézfogás Alapítvány nyertes pályázatainak ügyeit is kezelik.

\section{Helyi szint}

A települések kidolgozzák és jóváhagyják a község, a város fejlesztési programját és biztosítják annak végrehajtását. A járási vagy megyei hivatalok, illetve ma már a megyei önkormányzat kérésének megfelelően gondoskodnak a szükséges segítségről a megyei fejlesztési koncepció és a fejlesztési program elökészítésében és végrehajtásában. Az általánosan kötelező szabályozás segítségével biztosítják a település fejlesztésének támogatását, összefognak a szomszédos településekkel és más szervezódésekkel, kezdeményezik a közös fejlesztést (NPRD 2001, 52-55).

Az 1990 óta létező önkormányzati törvény lehetôvé teszi az egyes települési önkormányzatok társulását. A szlovákiai városok és falvak ezt követően létre is hozták szövetségüket (Falvak és Városok Szövetsége - szlovák rövidítése: ZMOS). Ez a szervezet politikai jelentőséggel bír, komoly jogi szerepe van, mert a különbözö kőzigazgatási változások, jogszabályok, rendeletek, költségvetési döntések elökészítésekor döntést befolyásoló szerepe lett.

A Szővetség tanácsadással segíti az országban létrejött 57 társulást. Ezen belưl további kisebb alkalmi társulások is vannak, alkalmazkodva egy-egy kisebb tájegység sajátos problémáihoz. Például a kassai kerület két nagy társulása (16+98 település) közuil a nagyobbik tovább bontódik hét kistérségre.

Ezek a társulások alkalmi feladatokra szerveződnek, azonban van példa az állandóbb, már jogi személyiségủ településszövetségek létrehozására is. Ilyen például a 34 község által létrehozott Felső-Bodrogközi Településszövetség, vagy a 18 községből álló Ungi Településszövetség. Sajátos a müködésükben, hogy megalakulásuk idején a város (Királyhelmec) regionális osztályán fogalmazták meg a hivatal szakemberei a településszövetségek programjait, a fejlesztési koncepciókat. Itt készültek a víz- és gázvezeték, a csatornázás fejlesztésének tervei, de a természetvédelmi, turisztikai beruházások elökészítése is. 
Van arra is példa, hogy nem a város szervezi a településszövetséget, hanem maguk a falvak. Így jött létre a Bódva-völgyi Településszövetség, Torna polgármesterének szervezésében. Közösen készitettek stratégiát a szövetség sajátos helyzetének figyelembevételével. Ez a helyzet módosul, megváltozik a kistérségi/járási fejlesztési ügynökség megalakulásával. A polgármesteri hivatalban 2001-ben helyet kapó ügynökség fogja ezeket a feladatokat átvenni azzal a munkamegosztással, hogy tevékenysége inkább a klasszikus területfejlesztésre, vállalkozások támogatására fog szorítkozni, a településfejlesztés infrastrukturális beruházásai pedig a hivatal hatáskörében maradnak.

\section{A területfejlesztés gyakorlata}

\section{A PHARE program}

1990-től kezdődően a PHARE volt az az európai támogatási forma, amely Szlovákia társadalmi-gazdasági fejlesztéséhez elöször adott formát és pénzügyi segítséget. Ezzel sikerült a területfejlesztést intézményesíteni, mert a közigazgatás megfelelő szereplői kaptak lehetőséget a módszer elsajátításához. Ezzel előkészültek a Strukturális Alapok fogadására is.

1997-ben 43,58 millió eurót sikerült megkapni. Ezt az összeget az ipari vállalkozások szerkezeti reformjára, a kis- és közepes vállalkozások fejlesztésére, az export és a külföldi befektetések ösztönzésére, a mezőgazdasági integrációk erősítésére, a civil társadalom fejlesztésére és egyéb közösségi programokra (Leonardo, Socrates, Youth for Europe) használták fel.

Az 1998-ban kapott 78,32 millió eurót a jogharmonizációra, a mezỏgazdaságra, a környezetvédelmi intézményrendszer kiépítésére, közösségi programokra, az iglói (Spiská Nová Ves) cigányok helyzetének javítására, a nagyméretü infrastrukturális beruházásokra, a Pozsonyt elkerülö kơzút építésére és a határon átnyúló kapcsolatok fejlesztésére használták fel.

1999-ben 69,5 millio eurót kőlthettek a nemzeti PHARE programra. Ezzel segítették a gazdasági reformot, a mezỏgazdaságot, a környezetvédelmet, az energiatermelést, az Esztergom-Párkány közötti híd fölépítését, a határon átnyúló kapcsolatokat.

\section{A vidékfejlesztés}

A vidéki területek problémáinak megoldása érdekében 1999-ben és 2000-ben az Európa Tanács és a szlovák kormány támogatásával jött létre a PHARE Vidékfejlesztési Alap. Ennek a beruházásnak az volt a célja, hogy létrehozzák a források átlátható elosztásának eszközét, és biztosítsák a vidékfejlesztés mechanizmusát. A kiválasztott területek az érsekújvári (Nové Zámky) és a szinnai-sztropkói (SninaStrokov) járás voltak.

Az Európai Unió a SAPARD programmal törekszik pénzügyi segítséget nyújtani az előcsatlakozás időpontjában. Ez a program a vidékfejlesztésre és a mezőgazda- 
ságra koncentrál. A támogatás feltétele a Nemzeti Vidékfejlesztési Terv megléte volt 2000 és 2006 közötti évekre (NPRD 2001, 56-58).

\section{Összefoglalás}

Magyarorszăg és a szomszédos Szlovákia között több hasonlóságot fedezhetünk fel az életszínvonal, a gazdaság fejlettsége, a társadalmi és politikai viszonyok tekintetében, mint köztük és a tőlük nyugatabbra fekvő tagállamok között. A földrajzi-történelmi közelség miatt nyilvánvaló hasonlóság ellenére sok eltérés van a két ország között, amely eltéréseket az aszimmetria fogalmával illethetünk. Kimutatható, hogy a szlovák politika a meglévő különbségeket törekszik minél erősebben rögzíteni, pl. a közigazgatás területi felosztásában, miközben tartalmilag megindult a közeledés az önkormányzatiság elvének érvényesítése irányába. Mivel az aszimmetriák mögül fölsejlik a politikai-etnikai szándékosság, állítható, hogy az uniós taggá válást követöen is hosszú időszakon keresztül megmaradnak a gyorsabb közeledést gátló akadályok.

\section{Jegyzetek}

1 „Az MKP ellenzi, hogy a közigazgatási reform kentauri törvény legyen: emberarcú állat, kifelé Nyugat, belsőleg Bizánc. Nagyon remélem, hogy az állam, amelyet itt közösen képviselüink, nem kerekedik saját polgárai fölé." Bugár Béla megjegyzése a szlovák palament vitájában, 2001. augusztus 26-án. Idézi: Új Szó 2001. augusztus 27.

${ }^{2}$ A szlovák törvények szerint az államigazgatás felügyelete alá tartoznak a vállalkozások. Itt kapják meg a müködésúkhöz szükséges engedélyeket, itt regisztrálják öket. A vita azon van, hogy ez a jogkör megmaradjon-e a járásoknál, vagy a településekhez kerüljön, ahol jobban ismerik az igényeket.

\section{Irodalom}

Bartakovic L.-Rittenbacher Ö.-Rabely A.-Tóth E. (2000) Regionális fejlesztési együttmüködés Heves megye és a rimaszombati járás között. I-II. kötet, Heves megyei Vállalkozási és Területfejlesztési Alapítvány, Eger.

Duray M. (2000) Változások küszöbén. Pro Minoritate könyvek. Osiris Kiadó, Budapest.

Document (200I) Document of the World Bank. Report No. 2235I-SK. Slovak Republic Living Standards, Employment and Labor Market Study, August 9.

Csehszlovákia II. (é.n.) Magyar Nemzeti Bank Közgazdasági, Tanulmányi és Statisztikai Osztály. Lelöhely: KSH, Budapest.

Gaál L. (2000) Összefüggö válságövezetünk. Interjú Berényi Józseffel, a pozsonyi régiófejlesztési föosztály vezetöjével. - ÚJ SZÓ. október 26.

Giddens, A. (1995) Szociológia. Osiris Kiadó, Budapest.

Halász I. (2001) A regionális önkormányzatok és az átfogó közigazgatási reformok a „visegrádi csoport" országaiban. - Szigeti Ernö (szerk.) Régió, közigazgatás, önkormányzat. Magyar Közigazgatási Intézet, Budapest. 43-64. o.

Mezei I. (2000) A fiatalok képzettségének területi jellemzői. - Horváth Gy.-Rechnitzer J. (szerk.) Magyarország terilleti szerkezete és folyamatai az ezredfordulón. MTA RKK, Pécs. 489-508. o.

Negotiation (2000) Negotiation Position of the Slovak Republic. Chapter 21. Regional Policy and Co-ordination of Sructural Instruments, Bratislava.

NPRD (2001) National Plan of Regional Development of the Slovak Republic. The Ministry of Construction and Regional Development of the Slovak Republic, Bratislava. 
Petőcz K. (1998) Választások és felosztások. Lilium Aurum, Dunaszerdahely.

Popély Gy. (1995) Ellenszélben. A felvidéki magyar kisebbség elsó évei a Csehszlovák Köztársaságban (1918-1925). Kalligram, Pozsony.

Suli-Zakar I. (2000) A Kårpátok Eurégió szerepe az átalakuló Közép-Európa határon átnyúló kapcsolataiban. - Abonyiné Palotás J.-Becsei J.-Kovács Cs. (szerk.) A magyar társadalomfóldrajzi kutatás gondolatviläga. Szegedi Tudományegyetem Gazdaság- és Társadalomfơldrajzi Tanszék, Szeged. 193-210. o.

Tuba L. (2000) Gazdasági szerkezet, üzleti élet, területfejlesztési tervek, idegenforgalom. - Bihari Z. (szerk.) Magyarok a világban - Kárpát-medence. CEBA Könyvkiadó, Budapest. 